\title{
REVISED Under-reported COVID-19 cases in South Asian
}

\section{countries [version 2; peer review: 3 approved]}

\author{
Soban Qadir Khan (D1, Imran Alam Moheet (DD2,3, Faraz Ahmed Farooqi (iD)4, \\ Muhanad Alhareky6, Faisal Alonaizan (iD)
}

1Department of Dental Education College of Dentistry, Imam Abdulrahman Bin Faisal University (IAU), Dammam, Saudi Arabia
2Department of Science Dental Material, Azra Naheed Dental College, Superior University, Lahore, Pakistan
${ }^{3}$ Department of Science Dental Material, Baqai Dental College, Baqai Medical University, Karachi, Pakistan
${ }^{4}$ Department of Academic Affairs, College of Dentistry, Imam Abdulrahman Bin Faisal University, Dammam, Saudi Arabia
5Department of Dental Education, College of Dentistry, Imam Abdulrahman Bin Faisal University, Dammam, Saudi Arabia
6Department of Preventive Dental Sciences, College of Dentistry, Imam Abdulrahman Bin Faisal University, Dammam, Saudi Arabia
${ }^{7}$ Department of Restorative Dental Sciences, College of Dentistry, Imam Abdulrahman Bin Faisal University, Dammam, Saudi Arabia

V2 First published: 10 Feb 2021, 10:88

https://doi.org/10.12688/f1000research.36705.1

Latest published: 17 Mar 2021, 10:88

https://doi.org/10.12688/f1000research.36705.2

\section{Abstract}

Background: The purpose of the study was to compare trends in the progression of COVID-19 among South Asian countries with more developed Western countries.

Methods: COVID-19 data from South Asian countries were used for this observational study. Data were taken up to April 21, 2020 from the outbreak of the COVID-19. Four of the seven countries met the inclusion criteria and were included in the analysis.

Results: An exponential increase in the average number of weekly cases was reported after the fifth week following the first case. The correlation between reported cases and tests was found to be strong and significant $(r=0.90, p=0.037)$. However, on average, 315.25 tests per million population were performed, which was at least 12 times lower than the number of tests performed in countries with a large number of COVID-19 cases.

Conclusions: At present, the number of confirmed cases from South Asia was found to be significantly lower than in Western countries. Hence, an increase in the strength of performing diagnostic tests is highly recommended. Strict measures are required to make the people of these countries follow the instructions of social distancing and comply with preventive measures.

Keywords

COVID-19, coronavirus disease, SARS-CoV-2, South Asia, pandemic

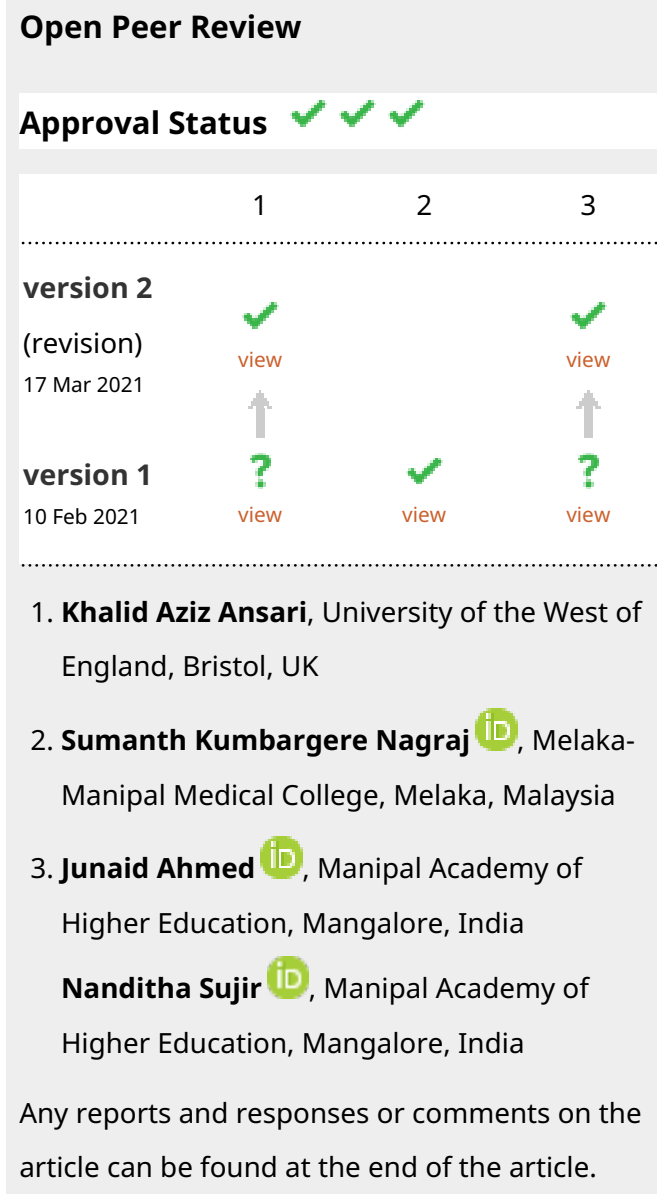

1. Khalid Aziz Ansari, University of the West of England, Bristol, UK

2. Sumanth Kumbargere Nagraj (D), Melaka-

Manipal Medical College, Melaka, Malaysia

3. Junaid Ahmed ID, Manipal Academy of Higher Education, Mangalore, India Nanditha Sujir (D), Manipal Academy of Higher Education, Mangalore, India Any reports and responses or comments on the article can be found at the end of the article. 


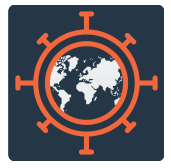

This article is included in the Emerging Diseases

and Outbreaks gateway.

collection.

\section{Corresponding author: Soban Qadir Khan (sqkhan@iau.edu.sa)}

Author roles: Khan SQ: Conceptualization, Data Curation, Writing - Original Draft Preparation; Moheet IA: Writing - Original Draft Preparation, Writing - Review \& Editing; Farooqi FA: Data Curation, Formal Analysis; Alhareky M: Writing - Original Draft Preparation, Writing - Review \& Editing; Alonaizan F: Project Administration, Writing - Review \& Editing

Competing interests: No competing interests were disclosed.

Grant information: The author(s) declared that no grants were involved in supporting this work.

Copyright: ( 2021 Khan SQ et al. This is an open access article distributed under the terms of the Creative Commons Attribution License, which permits unrestricted use, distribution, and reproduction in any medium, provided the original work is properly cited.

How to cite this article: Khan SQ, Moheet IA, Farooqi FA et al. Under-reported COVID-19 cases in South Asian countries [version 2; peer review: 3 approved] F1000Research 2021, 10:88 https://doi.org/10.12688/f1000research.36705.2

First published: 10 Feb 2021, 10:88 https://doi.org/10.12688/f1000research.36705.1 


\section{REVISED Amendments from Version 1}

Some explanations and references have been added in Introduction and Method section. In Discussion, some revisions have been made according to the reviewer comments hence first and last paragraphs of Discussion have been modified.

Any further responses from the reviewers can be found at the end of the article

\section{Introduction}

Any outbreak of an infectious disease or a natural disaster on a large scale, which spreads over a large geographical area leading to morbidity and mortality, is known as a pandemic. Evidence suggests that the likelihood of pandemics has increased over the past century because of an increase in global travel, urbanization, and greater exploitation of the natural environment ${ }^{1}$. Consequences of pandemics are multidimensional, have an impact on global health, socioeconomic conditions, and political implications ${ }^{2}$. The recent outbreak of coronavirus disease (COVID-19) was reported in the Huanan Seafood Market in Wuhan, China. China is therefore considered as the epicenter of the disease ${ }^{3}$. However, in the current scenario, some European countries and the United States of America (USA) have become new epicenters of the disease. Individually, these countries have more than twice the number of reported cases when compared to China. Meanwhile, their death toll is at least five times greater than in China ${ }^{4}$. During the second week of March, the COVID-19 outbreak was declared a pandemic by the World Health Organization (WHO) $)^{5}$.

The severe acute respiratory syndrome coronavirus 2 (SARSCoV-2) that causes COVID-19, belongs to the same family of corona viruses that includes the Middle East respiratory syndrome virus (MERS-CoV) ${ }^{6}$. Signs and symptoms of COVID-19 include respiratory symptoms, fever, cough, and shortness of breath. These breathing difficulties can worsen over time, and the disease can lead to complications such as: pneumonia, severe acute respiratory syndrome, kidney failure, and even death. People with low immunity and underlying systemic diseases are more prone to SARS-CoV-2 infection?. This is why the highest death rates are reported in the elderly population among those who were infected by COVID- $19^{8}$.

Various precautionary methods have been adapted by countries to control and stop the spread of COVID-19. A few such measures include hygiene maintenance, public awareness, partial lockdown, complete lockdown, and even the imposition of curfews ${ }^{9}$. Currently, social distancing is the only recognized way to prevent the spread of the virus. Hence, countries are making decisions based on their circumstances and the experiences of other countries ${ }^{10}$. Based on data extracted from the WHO database, the progression of the disease and deaths in various regions and countries differ ${ }^{11}$. Statistics show a high number of reported COVID-19 cases and deaths in some European countries and in the USA as well. The first confirmed case of COVID-19 in some South Asian countries like India and
Sri Lanka was reported on $15^{\text {th }}$ of February 2020 while in Pakistan and Bangladesh, the first confirmed case was reported on $26^{\text {th }}$ February and $8^{\text {th }}$ March respectively. The trend in average weekly increases in reported cases remained untested. Therefore, the objective of the current study was to find the trend in the progression of COVID-19 among South Asian countries compared to more developed Western countries.

\section{Methods}

This observational study was conducted between $20^{\text {th }}$ April and 22 $2^{\text {nd }}$ April 2020. The study included COVID-19 data available from worldometer ${ }^{12}$. Data was extracted from the date of the first COVID-19 case reported up until 21 ${ }^{\text {st }}$ April 2020. Data was extracted for all South Asian countries that were affected by the current outbreak. Only countries with at least 100 reported cases by $21^{\text {st }}$ April 2020 were included in the study and reason to do so was to prevent the analysis process from outliers' effects as well as to keep pictorial presentation visualized. Hence, a total of four out of the seven countries were included in the study: India, Pakistan, Sri Lanka, and Bangladesh.

The variables taken from the data source were: (1) total reported cases, (2) total deaths, (3) total recovered, (4) number of cases with outcome, (5) number of serious/critical cases, (6) total cases per one million population, (7) total tests performed, and (8) total tests performed per one million population. Furthermore, a few more variables were calculated using the extracted data and variables. The total outcome was calculated by adding the total number of deaths and the total number of recoveries. Percentage of deaths was calculated by using the equation [total deaths / (total deaths reported + total recovered) $\mathrm{x} 100 \%]$, the percentage of recovered cases was calculated as [total recovered/ (total deaths reported + total recovered) $\mathrm{x} 100 \%$ ], the percentage of critical cases as "number of critical cases/active cases $\times$ $100 \%$ ", and the ratio of the number of cases tested by dividing the total number of cases by the total number of tests performed. The weekly number of cases reported after the first case reported until $21^{\text {st }}$ April 2020 was also extracted from the data source. For the descriptive comparison of the present study's findings of countries with a high number of COVID-19 cases, some of the statistics are summarized in Table $1^{10}$.

The statistical package for social sciences (SPSS v. 23) was used for the analysis. Descriptive statistics included the calculation of averages and standard deviations as well as line graphs to present the number of weekly reported cases in each country. In inferential statistics, a simple linear regression was used between total cases (dependent variable) and total tests performed (independent variable). The Wilcoxon signed-ranks test was used to analyze the weekly increase in COVID-19 cases.

\section{Results}

The total number of reported COVID-19 cases in South Asian countries by $21^{\text {st }}$ April 2020 were 31,565 of which 5,526 (17.5\%) recovered. The number of reported deaths was 901. Among South Asian countries, India had the highest number of positive 
Table 1. Data for COVID-19 extracted from worldometer ${ }^{\circledR}{ }^{10}$.

\begin{tabular}{|l|c|c|c|c|c|}
\hline Countries & $\begin{array}{c}\text { No. of reported } \\
\text { cases }\end{array}$ & $\begin{array}{c}\text { No. of deaths } \\
\text { reported }\end{array}$ & $\begin{array}{c}\text { No. of recovered } \\
\text { cases }\end{array}$ & $\begin{array}{c}\text { No. of tests performed } \\
\text { per million }\end{array}$ & $\begin{array}{c}\text { Population } \\
\text { (per } \mathbf{~ k m}^{\mathbf{2}} \mathbf{~}\end{array}$ \\
\hline USA & 792,938 & 42,518 & 72,389 & 12,167 & 36 \\
\hline Spain & 204,178 & 21,282 & 82,514 & 19,896 & 94 \\
\hline Italy & 181,228 & 24,114 & 48,877 & 23,122 & 206 \\
\hline France & 155,383 & 20,265 & 37,409 & 7,103 & 119 \\
\hline UK & 124,743 & 16,509 & N/A & 7,386 & 75 \\
\hline China & 82,758 & 4,632 & 77,123 & & 153 \\
\hline Turkey & 90,980 & 2,140 & 13,430 & 7,991 & 110 \\
\hline Iran & 83,505 & 5,209 & 59,273 & 4,203 & 52 \\
\hline
\end{tabular}

COVID-19 cases $(18,658 ; 59.1 \%)$, followed by Pakistan $(9,216$; $29.2 \%)$, Bangladesh $(3,382 ; 10.7 \%)$, and Sri Lanka $(309 ; 1 \%)$ (Table 2). The percentage of reported deaths was highest in Bangladesh (55.84\%), followed by India (15.32\%), Sri Lanka (6.54\%), and Pakistan (8.5\%).

Figure 1 shows the exponential growth in the number of reported cases among the South Asian countries after the fourth to fifth week since the start of the disease. A sharp increase was observed in reported cases in India from the sixth week onwards. In Pakistan, the number of reported cases was also found to increase at the start of the fourth week. However, the spread of the virus was not as rapid in Bangladesh and Sri Lanka, as was found in the Indian and Pakistani populations. A comparison of the average number of reported cases in each week with the previous week revealed that the average increase in cases was not statistically significant except between fifth and sixth week (z-value -2.02, p-value 0.043). Figure 2 presented descriptive comparison of the average number of confirmed cases between two consecutive weeks.

On average, 315.25 tests per million population were performed in the countries included in the current study. A correlation between the total reported cases and the total number of tests performed was found. The data revealed a very strong, direct, and statistically significant correlation $(r=0.90, p=0.037)$. The Bangladeshi population had the highest percentage of tested positive cases in relation to the total number of tests performed $(12.71 \%)$, followed by Pakistan (8.24\%), Sri Lanka (4.78\%), and India (4.65\%).

The regression model between the number of tests performed (independent variable) and total number of cases reported (dependent variable) demonstrated a very strong $\mathrm{R}$-square value 0.925 with significance of the model $(\mathrm{p}=0.025)$. The predicted values of constant and slope for the model were 1442.4 and 0.045 , respectively. Hence, the regression equation can be written as

No. of cases reported $=1442.4+0.045$ (No. of tests performed)

\section{Discussion}

This study particularly highlighted the importance of maintaining data of COVID-19 patients and it indicated underestimation of COVID-19 positive cases in South Asian countries. Another important aspect of the findings was it regressed a model which found number of tests performed had significant and strong relation with number of cases. By comparing Table 1 and Table 2, difference in number of tests performed (per million) among countries with high number of COVID-19 cases (Table 1) and in South Asian countries (Table 2) can be seen.

As of $21^{\text {st }}$ April 2020, there had been over 2.5 million reported cases of COVID-19 in 210 countries across six continents. At the beginning of this pandemic, China $(82,758)$ was affected the most by the disease; however, later the USA $(792,938)$, Spain (204,178), Italy (181,228), France (155,383), Turkey $(90,980)$, and Iran $(83,505)$ had the most COVID-19 cases worldwide. The number of reported cases has since started to increase in South Asian countries (India, Pakistan, Sri Lanka, and Bangladesh). The initial cases reported in South Asian countries were thought to be caused by travelers returning from other COVID-19 affected countries. Although, by the date $\left(21^{\text {st }}\right.$ April, 2020), the total number of reported cases in South Asian countries is not as high as it was in the USA, Italy, Spain, France, and Iran (Table 1). However, the weekly growth in the number of reported cases (up to the eighth week) in South Asian countries is quite similar to the increase in the number of reported cases in the USA, France, and the United Kingdom (UK).

Based on the preparedness index formulated by Greenhill and Oppenheim, which defines the ability of a country to curtail any pandemic ${ }^{13}$, the spread risk of this pandemic is higher in South Asian developing countries than in developed countries ${ }^{14}$. A few of the factors that contribute to a higher spread risk of the pandemic include population density, susceptibility to infection, patterns of movement driven by travel, trade, and migration, the speed and effectiveness of public health surveillance 
Table 2. Country-wise extracted and computed variables after inclusion criteria for South Asian countries.

\begin{tabular}{|l|c|c|c|c|c|c|c|}
\hline Countries & Cases & Deaths & Recovered & OUTCOME & $\begin{array}{c}\text { Death } \\
\text { (\%) }\end{array}$ & Recovered (\%) & $\begin{array}{c}\text { No. of tests performed } \\
\text { per million pop. }\end{array}$ \\
\hline India & 18,658 & 592 & 3,273 & 3,865 & 15.32 & 84.68 & 291 \\
\hline Pakistan & 9,216 & 192 & 2,066 & 2,258 & 8.50 & 91.50 & 506 \\
\hline Sri Lanka & 309 & 7 & 100 & 107 & 6.54 & 93.46 & 302 \\
\hline Bangladesh & 3,382 & 110 & 87 & 197 & 55.84 & 44.16 & 162 \\
\hline
\end{tabular}

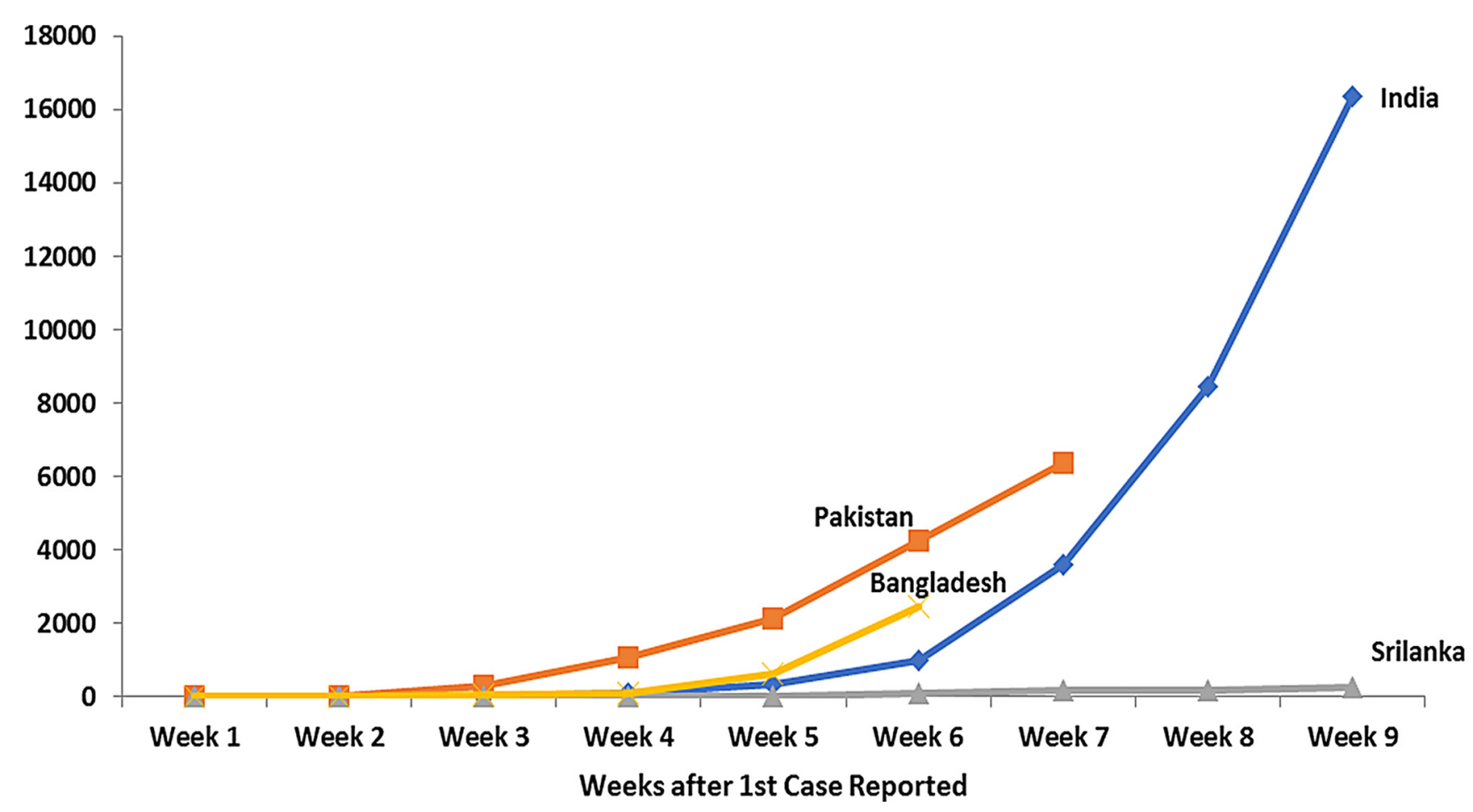

Figure 1. Weekly comparison of reported COVID-19 cases.

and response measures, and the socioeconomic status of the country ${ }^{14}$. Three out of four countries included in the current study fall under the top ten most populated countries in the world $\mathrm{d}^{15-17}$. Furthermore, the per $\mathrm{km}^{2}$ population in Bangladesh, India, and Pakistan is more than any country listed in Table 1. In addition, a large number of people in these countries live in slums ${ }^{15-17}$, which makes it difficult to maintain social distancing and to adopt preventive measures. Furthermore, poor education and extreme poverty are other factors that make it more difficult to follow social distancing instructions, or early disease identification of symptoms of COVID-19. A report from Pakistan showed an increasing number of cases where people died due to COVID-19 before reaching a hospital ${ }^{18}$.
To date, there has been a total of 2,505,858 reported cases of COVID-19 worldwide, with a lower number of reported cases $(31,608)$ and reported deaths (901) in South Asian countries compared to other regions of the world. There have been many hypotheses related to this lower reported COVID-19 cases and deaths. Some of the theories included stronger immunity, warmer weather, childhood BCG vaccinations, and exposure to antimalaria medications. From the data collected from the worldometer ${ }^{\circledR}$ website, the authors believe that the lower number of reported cases in the South Asian countries could be due to the lower number of diagnostic tests performed for COVID-19 virus compared to countries that have reported a higher number of COVID-19 cases. India $(18,658)$ and Pakistan $(9,216)$ 


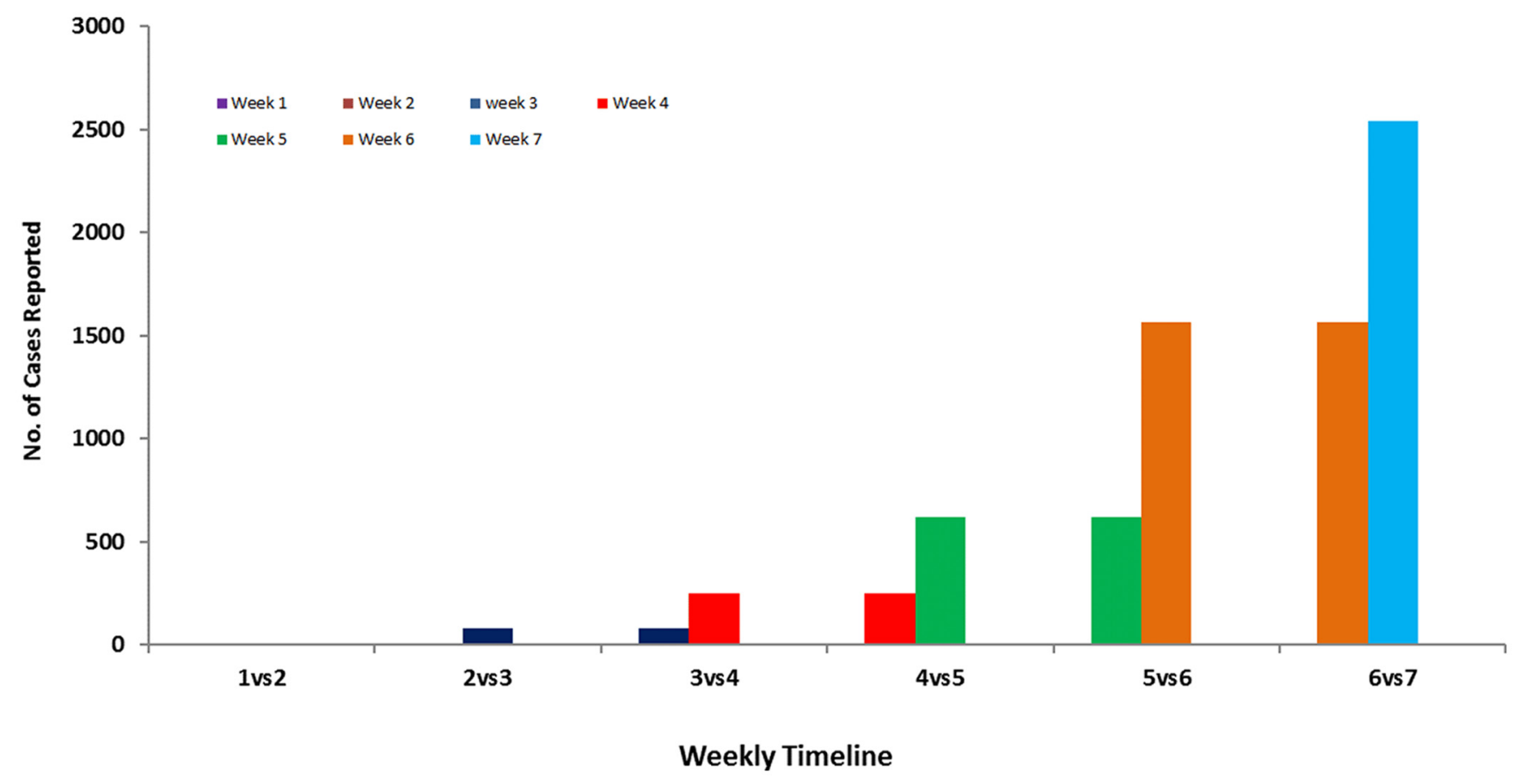

Figure 2. Weekly comparison of reported cases for South Asian countries.

have the most COVID-19 cases in South Asian countries, with 291 and 506 tests performed per million population, respectively. The number of tests (per million) performed in India and Pakistan is significantly lower than in the USA $(12,167)$, Spain (19,896), Italy (23,122), France (7,103), and the UK (7,386). Even countries in Asia with the highest number of COVID-19 cases, Turkey $(7,991)$ and Iran $(4,203)$, have a higher number of tests performed per million population. In South Asia, on average, 315.25 tests per million population were performed; this is at least 12 times lower than the number of tests performed in the epicenters of COVID-19.

Even though the world is better prepared to face any health crisis than before, still the world is not fully prepared to handle a pandemic. Preparedness for any crisis does affect from financial status of any country hence financially strong countries would have better chances to have more health care facilities, resources, infrastructures to cope with any crisis. In present time, world is facing a pandemic and so far, its deep impact can be seen in various continents however it is not significantly hit south Asian countries yet.

Accountability for preparedness in these countries is diffuse, and many countries that are at the greatest risk have the most limited capacity to manage and mitigate pandemic risk. In addition, these countries need to perform the virus diagnostic tests in greater numbers to get an accurate picture of the pandemic. Based on the data, one could suggest that the low number of reported cases but with high percentage increases for South Asian countries could be a ticking time bomb waiting to explode, and this region could be the next highlighted region of this current pandemic.

\section{Conclusions}

Although the current number of reported cases and reported deaths from South Asia suggested that the spread of COVID-19 is not as high as it was in many other countries. However, a comparison of statistics and population characteristics does not portray a good picture for the future. Therefore, the following conclusions can be drawn:

1. One side of the picture is a lower number of reported cases and deaths, but the other side of the picture suggests a large number of cases that are prevailing in the society that are unidentified and undiagnosed. Hence, identifying the spread of the disease by increasing the number of diagnostic tests is highly recommended.

2. Governments in these countries are required to take strict measures such as partial or complete lockdowns in order to maintain proper social distancing, since a high population density coupled with low education levels and low disease awareness could lead to a new disease epicenter.

\section{Data availability}

Underlying data

Harvard Dataverse: Low Reported COVID-19 Cases in South Asian Countries: A Luck of Nature or A Ticking Time Bomb, https://doi.org/10.7910/DVN/QLTVRW ${ }^{19}$. 
Data are available under the terms of the Creative Commons Zero "No rights reserved" data waiver (CC0 1.0 Public domain dedication).

\section{Author information}

Imran Alam Moheet was affiliated with Azra Naheed Dental College, Superior University, Pakistan at the time this paper was written but is currently at Baqai Dental College, Baqai Medical
University, Pakistan. Faraz Ahmed Farooqi was affiliated with Department of Academic Affairs, Imam Abdulrahman Bin Faisal University, Saudi Arabia at the time this paper was written but is currently affiliated with Department of Dental Education, Imam Abdulrahman Bin Faisal University, Saudi Arabia.

\section{Acknowledgements}

A previous version of this article is available on Research Square: https://doi.org/10.21203/rs.3.rs-33960/v2
1. Jones KE, Patel NG, Levy MA, et al.: Global trends in emerging infectious diseases. Nature. 2008; 451(7181): 990-93. PubMed Abstract | Publisher Full Text | Free Full Text

2. Jamison DT, Gelband H, Horton S, et al.: Disease control priorities: improving health and reducing poverty. In: 3rd ed. Washington (DC): The International Bank for Reconstruction and Development/The World Bank; Chapter 17. 2017. PubMed Abstract | Publisher Full Text

3. Zhou F, Yu T, Du R, et al.: Clinical course and risk factors for mortality of adult inpatients with COVID-19 in Wuhan, China: a retrospective cohort study. Lancet. 2020; 395(10229): 1054-1062.

PubMed Abstract | Publisher Full Text | Free Full Text

4. World Health Organization: Coronavirus disease 2019 (COVID-19): situation report, 85. 2020. Reference Source

5. World Health Organization: WHO director-general's opening remarks at the media briefing on COVID-19. 11 Mar 2020. Reference Source

6. CDC: Coronavirus Disease (COVID-19): Situation Summary. Accessed $14 \mathrm{Apr}$ 2020.

Reference Source

7. Abdulamir AS, Hafidh RR: The possible immunological pathways for the variable immunopathogenesis of COVID-19 infections among healthy adults, elderly and children. Electron J Gen Med. 2020; 17(4): em202. Publisher Full Text

8. Dowd JB, Rotondi V, Adriano L, et al.: Demographic science aids in understanding the spread and fatality rates of COVID-19. medRxiv. 2020. Publisher Full Text

9. Kaplan J, Frias L, Johnsen M: A third of the global population is on coronavirus lockdown-here's our constantly updated list of countries and restrictions. Business Insider News. 14 Apr 2020. Reference Source
10. Kaplan J, Frias L, Johnsen M: A third of the global population is on coronavirus lockdown - here's our constantly updated list of countries and restrictions. Business Insider News. Updated 14 April 2020. Reference Source

11. World Health Organization: Coronavirus (COVID-19). Accessed 19 Apr 2020.

12. Worldometer coronavirus cases. Accessed 21 Apr 2020. Reference Source

13. Greenhill KM, Oppenheim B: Rumor has it: the adoption of unverified information in conflict zones. Int Stud Q. 2017; 61(3): 660-76. Publisher Full Text

14. Sands P, El Turabi A, Saynisch PA, et al.: Assessment of economic vulnerability to infectious disease crises. Lancet. 2016; 388(10058): 2443-2448. PubMed Abstract | Publisher Full Text | Free Full Text

15. Marsh DR, Kadir MM, Husein K, et al.: Adult mortality in slums of Karachi, Pakistan. J Pak Med Assoc. 2000; 50(9): 300-6. PubMed Abstract

16. Johnson K: Census: 1 in $\mathbf{6}$ India city residents lives in slums. 22 Mar 2013. Accessed 21 Apr 2020 Reference Source`

17. Angeles G, Lance $\mathrm{P}$, Barden-O'Fallon J, et al.: The $\mathbf{2 0 0 5}$ census and mapping of slums in Bangladesh: design, select results and application. Int $J$ Health Geogr. 2009; 8(1): 32 PubMed Abstract | Publisher Full Text | Free Full Text

18. Bhatti MW: Why are Karachi's hospitals getting more DOAs, near-death patients? The News (International). 15 Apr 2020. Accessed 22 Apr 2020. Reference Source

19. Soban Q: Low Reported COVID-19 Cases in South Asian Countries: A Luck of Nature or A Ticking Time Bomb. Harvard Dataverse, V1, UNF:6: evfkN8AHLCnyrXwm5EbQOg== [fileUNF]. 2021. http://www.doi.org/10.7910/DVN/QLTVRW 


\section{Open Peer Review}

\section{Current Peer Review Status:}

\section{Version 2}

Reviewer Report 22 March 2021

https://doi.org/10.5256/f1000research.54941.r81572

(c) 2021 Ansari K. This is an open access peer review report distributed under the terms of the Creative Commons Attribution License, which permits unrestricted use, distribution, and reproduction in any medium, provided the original work is properly cited.

\section{Khalid Aziz Ansari}

Department of Physiology, University of the West of England, Bristol, UK

\section{2/07/2021: Added detail of a competing interest which recently came to light about this co-} authored article.

Author addresses all my comments comprehensively and the manuscript is now looks fine overall and can be indexed.

Competing Interests: Around a month before reviewing this article, an article was submitted (Perception on online teaching and learning among health sciences students in higher education institutions during the COVID-19 lockdown - ways to improve teaching and learning in Saudi colleges and universities) to F1000 which was a collaboration between myself and the co-authors of this article. This was published after completing my review and was not declared at the time.

Reviewer Expertise: Acute and Chronic lung diseases, epidemiology

I confirm that I have read this submission and believe that I have an appropriate level of expertise to confirm that it is of an acceptable scientific standard.

Reviewer Report 18 March 2021

\section{https://doi.org/10.5256/f1000research.54941.r81573}

(C) 2021 Ahmed J et al. This is an open access peer review report distributed under the terms of the Creative Commons Attribution License, which permits unrestricted use, distribution, and reproduction in any medium, provided the original work is properly cited.

\section{Junaid Ahmed}


Department of Oral Medicine and Radiology, Manipal College of Dental Sciences, Manipal Academy of Higher Education, Mangalore, India

\section{Nanditha Sujir}

Department of Oral Medicine and Radiology, Manipal College of Dental Sciences, Manipal Academy of Higher Education, Mangalore, India

The revised manuscript has been noted with no additional comments.

Competing Interests: No competing interests were disclosed.

We confirm that we have read this submission and believe that we have an appropriate level of expertise to confirm that it is of an acceptable scientific standard.

\section{Version 1}

Reviewer Report 24 February 2021

https://doi.org/10.5256/f1000research.39768.r79261

(c) 2021 Ahmed J et al. This is an open access peer review report distributed under the terms of the Creative Commons Attribution License, which permits unrestricted use, distribution, and reproduction in any medium, provided the original work is properly cited.

\section{Junaid Ahmed}

Department of Oral Medicine and Radiology, Manipal College of Dental Sciences, Manipal Academy of Higher Education, Mangalore, India

\section{Nanditha Sujir}

Department of Oral Medicine and Radiology, Manipal College of Dental Sciences, Manipal Academy of Higher Education, Mangalore, India

Thank you for the opportunity to review this article. This article is related to the most pressing health crises faced by mankind i.e COVID-19. The article is well written and adheres to the formatting of the journal.

Few points need clarification,

1. In the methodology, the authors state that only data from South Asian countries have been included. However, the data from other developed countries have also been included for comparison.

\section{Discussion:}

a) Kindly avoid restating the results in the discussion section.

b) The authors should discuss the variations in the COVID-19 testing policies that the 
countries adopted initially, as it is variable from country to country and can alter the number of tests. Also, in the discussion the authors should elaborate on the timings and implementation of the country wide lockdown in the countries, that could have affected the rate of spread of COVID-19.

Is the work clearly and accurately presented and does it cite the current literature? Yes

Is the study design appropriate and is the work technically sound?

Yes

Are sufficient details of methods and analysis provided to allow replication by others? Yes

If applicable, is the statistical analysis and its interpretation appropriate?

I cannot comment. A qualified statistician is required.

Are all the source data underlying the results available to ensure full reproducibility?

Yes

Are the conclusions drawn adequately supported by the results? Partly

Competing Interests: No competing interests were disclosed.

We confirm that we have read this submission and believe that we have an appropriate level of expertise to confirm that it is of an acceptable scientific standard, however we have significant reservations, as outlined above.

Reviewer Report 24 February 2021

https://doi.org/10.5256/f1000research.39768.r79263

(C) 2021 Kumbargere Nagraj S. This is an open access peer review report distributed under the terms of the Creative Commons Attribution License, which permits unrestricted use, distribution, and reproduction in any medium, provided the original work is properly cited.

\section{Sumanth Kumbargere Nagraj}

Department of Oral Medicine and Oral Radiology, Melaka-Manipal Medical College, Melaka, Malaysia

This is an observational study based on the data taken up to 21st April 2020. During this period South Asian countries mentioned in this study were already under lockdown (Bangladesh: from 22 March to 30 May; India: 24 March to 31 May and Sri Lanka: 26 March to 11 May). I do not understand why the authors conclude by suggesting lockdowns as their only suggestion. In contrast to their suggestion, today, these are the countries which are doing better compared to 
the countries which have or are still under lockdowns.

The authors have not considered the issues related to the population of India or Pakistan, the handful testing centres these countries had in the month of April with limited number of test kits and the availability of PPE kits in these four countries. Comparing a population of 1.3 billion (India) or 216 million (Pakistan) to countries with fraction of its population and suggesting lockdown looks futile. The economic impact of lockdown is another aspect which needs to be weighed before opting for a lockdown in these countries.

However, the article highlights the importance of social distancing and preventive measures that needs to be implemented in these countries which are the most economic preventive measures.

Is the work clearly and accurately presented and does it cite the current literature? Yes

Is the study design appropriate and is the work technically sound?

Partly

Are sufficient details of methods and analysis provided to allow replication by others? Yes

If applicable, is the statistical analysis and its interpretation appropriate? Partly

Are all the source data underlying the results available to ensure full reproducibility? Yes

Are the conclusions drawn adequately supported by the results?

Yes

Competing Interests: No competing interests were disclosed.

Reviewer Expertise: Evidence-based healthcare, qualitative evidence synthesis, Randomised controlled trials in Oral healthcare, Research priority setting

I confirm that I have read this submission and believe that I have an appropriate level of expertise to confirm that it is of an acceptable scientific standard.

Reviewer Report 15 February 2021

https://doi.org/10.5256/f1000research.39768.r79264

(C) 2021 Ansari K. This is an open access peer review report distributed under the terms of the Creative Commons Attribution License, which permits unrestricted use, distribution, and reproduction in any medium, provided the original work is properly cited. 
Khalid Aziz Ansari

Department of Physiology, University of the West of England, Bristol, UK

02/07/2021: Added detail of a competing interest which recently came to light about this coauthored article.

This is interesting study and following areas need a little more revision.

Introduction section:

There are some missing references. ("The recent outbreak...epicentres of the disease, Currently, social distancing is the only recognized way to prevent the spread of the virus. Hence, countries are making decisions based on their circumstances and the experiences of other countries...of other countries").

Method:

To add more clarity, it needs a little more justification on why countries with more than 100 cases were selected.

\section{Discussion:}

This section need major revision in relation to organisation. It does not clearly reflects the results of the study and the impact of present study findings in the these countries. For example, which of your study findings suggest that this disease is zoonotic?

Is the work clearly and accurately presented and does it cite the current literature? Partly

Is the study design appropriate and is the work technically sound?

Yes

Are sufficient details of methods and analysis provided to allow replication by others? Yes

If applicable, is the statistical analysis and its interpretation appropriate?

I cannot comment. A qualified statistician is required.

Are all the source data underlying the results available to ensure full reproducibility? Partly

Are the conclusions drawn adequately supported by the results?

Yes

Competing Interests: Around a month before reviewing this article, an article was submitted (Perception on online teaching and learning among health sciences students in higher education institutions during the COVID-19 lockdown - ways to improve teaching and learning in Saudi colleges and universities) to F1000 which was a collaboration between myself and the co-authors of this article. This was published after completing my review and was not declared at the time. 
Reviewer Expertise: Acute and Chronic lung diseases, epidemiology

I confirm that I have read this submission and believe that I have an appropriate level of expertise to confirm that it is of an acceptable scientific standard, however I have significant reservations, as outlined above.

Author Response 24 Feb 2021

soban khan, Imam Abdulrahman Bin Faisal University (IAU), Dammam, Saudi Arabia

Dear Khalid Aziz,

Thank you for your time you gave to review this article. I appreciate your comments which will help to improve presentation of our work. We have modified the manuscript to address your comments.

Many Thanks.

Competing Interests: No competing interests were disclosed.

The benefits of publishing with F1000Research:

- Your article is published within days, with no editorial bias

- You can publish traditional articles, null/negative results, case reports, data notes and more

- The peer review process is transparent and collaborative

- Your article is indexed in PubMed after passing peer review

- Dedicated customer support at every stage

For pre-submission enquiries, contact research@f1000.com 